
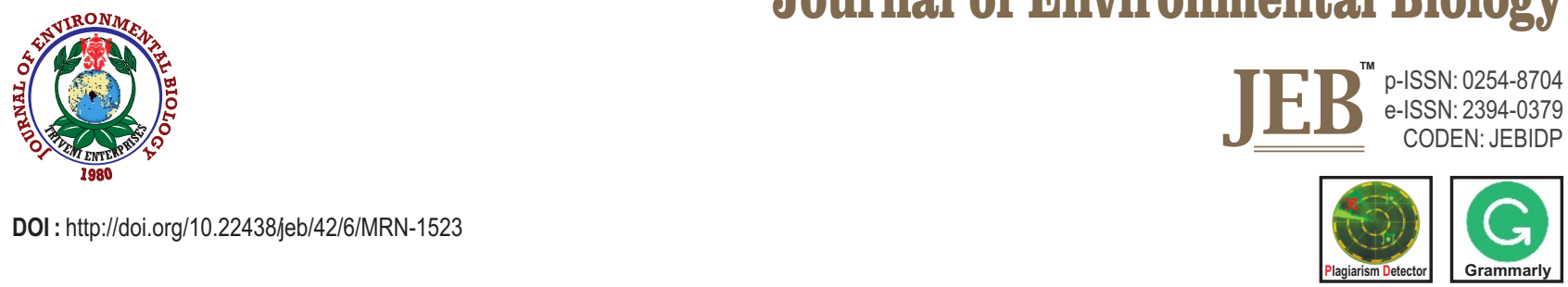

\title{
Amelioration of zinc deficiency in blackgram (Vigna mungo L.) through soil applied zinc in Typic Haplustepts soil of Rajasthan
}

\author{
G. Jat', S.K. Sharma ${ }^{2 *}$, R.H. Meena ${ }^{3}$, D. Jain ${ }^{4}$, R. Choudhary ${ }^{5}$, R.S. Choudhary ${ }^{5}$ and S.K. Yadav ${ }^{6}$ \\ 'Department of Soil Science and Agricultural Chemistry, Rajasthan College of Agriculture, MPUAT, Udaipur-313001, India \\ ${ }^{2}$ Directorate of Research, Maharana Pratap University of Agriculture \& Technology, Udaipur-313001, India \\ ${ }^{3}$ Department of Soil Science and Agricultural Chemistry, Rajasthan College of Agriculture, MPUAT, Udaipur-313001, India \\ ${ }^{4}$ Department of Molecular Biology and Biotechnology, Rajasthan College of Agriculture, MPUAT, Udaipur-313 001, India \\ ${ }^{5}$ Department of Agronomy, Rajasthan College of Agriculture, Maharana Pratap University of Agriculture \& Technology, Udaipur-313001, India \\ ${ }^{6}$ ICAR-Network Project on Organic Farming, Maharana Pratap University of Agriculture \& Technology, Udaipur-313001, India \\ *Corresponding Author Email : shanti_organic@rediffmail.com
}

\begin{abstract}
Aim: To study the amelioration of zinc deficiency in blackgram (Vigna mungo L.) through soil applied zinc in Typic Haplustepts soil of Rajasthan.
\end{abstract}

Methodology: A two year field experiment was undertaken during Kharif 2016 and 2017 at Instructional Farm (Agronomy), Rajasthan College of

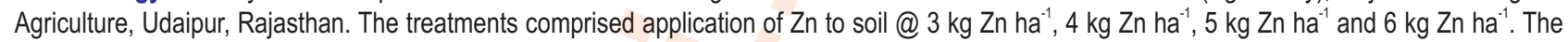
experiment was laid out in a randomized block design with four replications.

Results: Application of zinc significantly $(P=0.05)$ increased the number of nodules per plant, number of pods per plant, number of seeds per pod, seed yield, haulm yield, biological yield, nutrient ( $N$, $\mathrm{P}, \mathrm{K} \& \mathrm{Zn}$ ) content and uptake, protein content, net return and B:C ratio in blackgram. Soil application of Zn@5 kg ha ${ }^{-1}$ significantly increased seed yield, haulm yield and biological yield by 72.53 , 50.08 and 57.68 per cent over the control in pooled analysis, respectively. However, the effect of application of Zn@5 kg ha-1 on yield attributes, yield, nutrient content, uptake, quality and economics of blackgram was found statistically at par with the application of $6 \mathrm{~kg} \mathrm{Zn} \mathrm{ha}^{-1}$.

Interpretation: The application of Zn@ $5 \mathrm{~kg} \mathrm{ha}^{-1}$ along with the recommended dose of fertilizer (NPK) resulted in significantly $(P=0.05)$ higher productivity, nutrient uptake, quality and profitability of blackgram under Typic Haplustepts soil of Rajasthan.

Key words: Blackgram, Fertilizer, Typic Haplustepts soil, Zinc

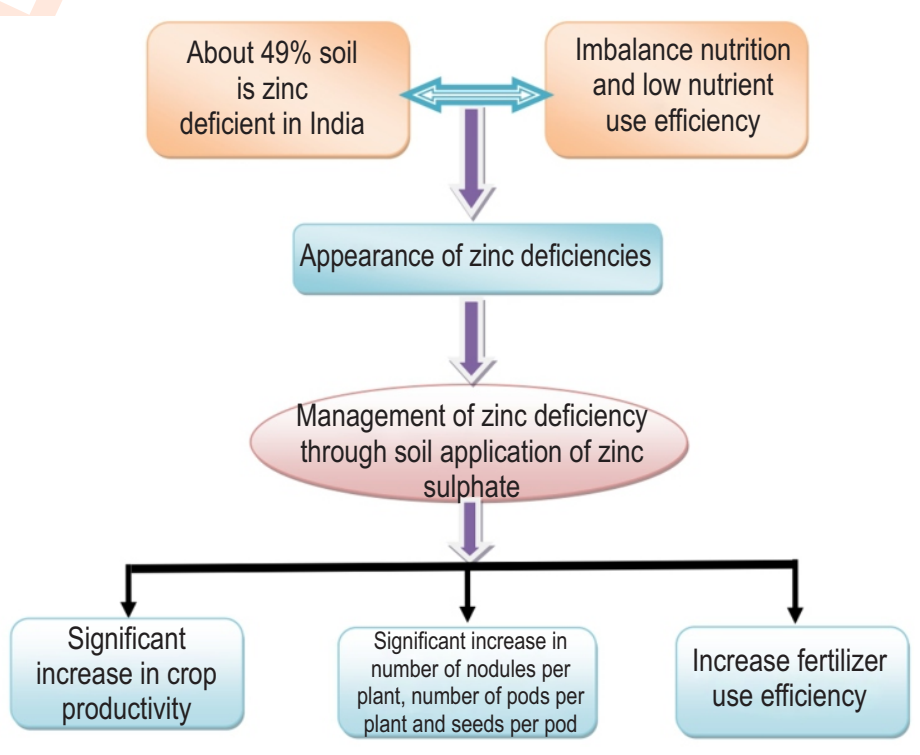

How to cite : Jat, G., S.K. Sharma, R.H. Meena, D. Jain, R. Choudhary, R.S. Choudhary and S.K. Yadav: Amelioration of zinc deficiency in blackgram (Vigna mungo L.) through soil applied zinc in Typic Haplustepts soil of Rajasthan. J. Environ. Biol., 42, 1554-1559 (2021). 


\section{Introduction}

Enhancing the productivity of pulses is the top priority to ensure food and nutritional security in India. Pulses are good source of proteins, minerals, vitamins and carbohydrates which plays an important role in human nutrition and is also known as poor man's meat (Mony et al., 2008). Pluses contain 20-24 per cent protein which is about 2.5 times than cereal grains and hence, offers the most practical means of eradicating malnutrition. Blackgram (Vigna mungo L.) is one of the important pulse crops in India and also a key Kharif pulse crop of Rajasthan. In Rajasthan, blackgram occupies 5.40 lakh ha area with a production of 3.37 lakh tones and productivity of $559 \mathrm{~kg} \mathrm{ha}^{-1}$ (Meena and Meena, 2020), which is low in consumption to yield in the other states. Among various factors, limiting the yield of blackgram deficiency of zinc in the soil is one of the important reason. Zinc is an essential micronutrient for required crop production. Zinc plays a key role as a structural, constituent or regulatory cofactor of a wide range of different enzymes and proteins viz. antioxidant enzymes which maintains the membrane lipids, proteins and nucleic acids in plant cells (Cakmak, 2008). Zinc has a key role in many important biochemical pathways like carbohydrate metabolism, photosynthesis, conversion of sugars to starch, protein metabolism, auxin (growth regulator) metabolism, pollen formation, integrity of biological membranes and resistance to infection by certain pathogens (Alloway, 2008). Zinc deficiency in plant and soil has been reported across the world (Alloway, 2008).

The intensive uses of minerals by crop plants have caused rapid zinc depletion causing zinc deficiencies in soil (Manojlovic et al., 2019). About $75 \%$ of the global population suffers from zinc deficiency and root cause of many health issues hence, zinc supplement in a balanced diet is the need of the hour (Singh, 2011; Aziz et al., 2018). In India, zinc is considered as the third important yield limiting nutrient after nitrogen and phosphorus (Takkar and Randhawa, 1978). There are estimates that more than $30 \%$ of agricultural soils globally are low in available zinc leading to deficiency in crops cultivated on these soils (Alloway, 2008). In India, zinc is one of the multi-nutrient deficiencies that are causing poor crop yields. Zinc deficiency in Indian soils is expected to increase from $42 \%$ in 1970 to $63 \%$ by 2025 due to continuous depletion of soil fertility (Arunachalam et al., 2013; Bhatt et al., 2020). Most soils of Rajasthan are coarse textured with low to medium organic carbon content and are deficient in zinc (Singh and Singh, 1981). Therefore, it becomes necessary to pay serious attention to the application and utilization of zinc. Application of zinc either through soil or through foliar application are important methods for improving grain zinc concentration (Cakmak, 2018). Crop plants have the capacity to absorb zinc through leaf surfaces, hence, foliar spray of zinc is best way for zinc application and its utilization in the growing tissue (Khoshgoftarmanesh et al., 2010). Keeping in view the key role played by zinc in plant growth, the present investigation was carried out in Typic Haplustepts soil of Rajasthan to study the amelioration of zinc deficiency in blackgram (Vigna mungo L.) through soil applied zinc.

\section{Materials and Methods}

Experimental site and soil: A two-year-field experiment was conducted during Kharif 2016 and 2017 at Instructional Farm (Agronomy), Rajasthan College of Agriculture, Udaipur situated under Sub-Humid Southern Plain and Aravalli Hill zone of Rajasthan. The average maximum and minimum temperature during rainy season (July-October) ranged between 26.5 to 35.6 ${ }^{\circ} \mathrm{C}$ and the average annual rainfall was $641 \mathrm{~mm}$. Soil was clay loam in texture, alkaline in $\mathrm{pH}(8.23+0.18)$ and electrical conductivity was normal $\left(0.61+0.05 \mathrm{dS} \mathrm{m}^{-1}\right)$, medium in organic carbon $(0.60 \pm 0.05 \%)$; low in available $\mathrm{N}\left(273.25 \pm 5.77 \mathrm{~kg} \mathrm{ha}^{-1}\right)$, available $\mathrm{P}_{2} \mathrm{O}_{5}\left(16.50 \pm 0.91 \mathrm{~kg} \mathrm{ha}^{-1}\right)$, high in available $\mathrm{K}_{2} \mathrm{O}(363.46$ $\left.\pm 6.42 \mathrm{~kg} \mathrm{ha}^{-1}\right)$ and low in available zinc $\left(0.592 \pm 0.074 \mathrm{mg} \mathrm{kg}^{-1}\right)$.

Experimental design and treatments: The experiment was laid out in randomized block design replicated four times in the plot size of $4.0 \mathrm{~m} \times 3.0 \mathrm{~m}\left(12 \mathrm{~m}^{2}\right)$ with five levels of zinc application, i.e. control $\left(T_{1}\right), 3.0 \mathrm{~kg} \mathrm{Zn} \mathrm{ha}^{-1}\left(T_{2}\right), 4.0 \mathrm{~kg} \mathrm{Zn} \mathrm{ha}^{-1}\left(T_{3}\right), 5.0 \mathrm{~kg} \mathrm{Zn} \mathrm{ha}^{-1}$ $\left(T_{4}\right)$ and $6.0 \mathrm{~kg} \mathrm{Zn} \mathrm{ha}^{-1}\left(\mathrm{~T}_{5}\right)$ as soil application. Seeds of $\mathrm{V}$. mungo var. PU-31 was sown in lines $30 \mathrm{~cm}$ apart.

Fertilizer application: Nitrogen @20 kg ha-1 was applied in two equal splits, the half dose of nitrogen as basal and the remaining half dose of nitrogen was top dressed at the time of first irrigation. The basal dose was applied through urea after adjusting the quantity supplied through diammonium phosphate. Phosphorus @40 kg ha ${ }^{-1}$ as diammonium phosphate and zinc as zinc sulphate were applied as basal and drilled at the depth of 8-10 cm along basal dose of nitrogen prior to sowing.

Observations recorded: Different yield characters like number of effective nodules per plant, number of pods per plant, number of seeds per pod, test weight, seed yield, haulm yield and biological yield were recorded and statistically analyzed for Analysis of Variance (ANOVA) (Panse and Sukhatme, 1985).

Nutrient content: The plant samples (seed and haulm) collected at harvest were air dried and powdered. Nitrogen content was estimated by the method of Snell and Snell (1949), phosphorus and potassium following the method of Jackson (1973) and zinc by Lindsay and Norvell (1978) method. Protein content was estimated by the method ofA.O.A.C. (1960).

Statistical analysis: The data recorded for different parameters were analyzed by analysis of variance (ANOVA). The results are presented at $5 \%$ level of significance.

\section{Results and Discussion}

The significantly maximum number of effective nodules per plant (32.64), number of pods per plant (32.08), number of seeds per pod (3.92) and test weight (41.46 g) was observed with the application of Zn@ $5 \mathrm{~kg} \mathrm{ha}^{-1}$ in pooled analysis. However, the effect of application of 5 and $6 \mathrm{~kg} \mathrm{Zn} \mathrm{ha}^{-1}$ was found statistically at par with respect to yield attributes in pooled analysis. The data 
further revealed that the per cent increase in the number of effective nodules per plant, number of pods per plant, number of seeds per pod and test weight were 39.96, 25.55, 71.17 and 7.99 in pooled analysis on applying $5 \mathrm{~kg} \mathrm{Zn} \mathrm{ha}^{-1}$ as compared to control (Table 1 and Fig. 1). The results of the present study were in the close agreement with Sharma and Abraham (2010) who studied the effect of zinc on blackgram and reported a significant difference in plant height, dry matter per plant, seeds per pod and pods per plant with zinc application. Upadhyay and Singh (2016) also reported a significant increase in plant growth, number of branches per plant, total dry matter, seeds per pod, number of pods per plant and test weight in cowpea due to application of zinc. Similarly, Dubey et al. (2013) and Jat et al. (2013) also reported an increase in growth parameters and yield attributes in different crops with the application of zinc. This has been due to increased availability of zinc in soil and higher uptake of zinc by plant which directly influenced various physiological and metabolic processes including nitrogen assimilation \& metabolism and auxin synthesis giving positive effect on plant growth (Roy et al., 2014). Zinc also helps in chlorophyll formation which has direct impact on plant growth (Cakmak, 2008). Besides, zinc also enhances the absorption of essential elements by increasing the cation exchange capacity of roots (Vedram et al., 2002). Thus, the application of zinc in a zinc deficient soil $(<$ $0.60 \mathrm{ppm} Z \mathrm{n}$ ), improved the overall growth and development of blackgram. Application of increasing levels of zinc from $3 \mathrm{~kg}$ to 6 $\mathrm{kg} \mathrm{Zn} \mathrm{ha}{ }^{-1}$ significantly increased the seed, haulm and biological yield of blackgram. The significantly maximum seed yield (903.86 $\left.\mathrm{kg} \mathrm{ha}^{-1}\right)$, haulm yield (1536.29 $\mathrm{kg} \mathrm{ha}^{-1}$ ) and biological yield $\left(2440.15 \mathrm{~kg} \mathrm{ha}^{-1}\right)$ of blackgram was recorded under Zn@ $5 \mathrm{~kg} \mathrm{ha}^{-1}$ in pooled analysis (Table 1). However, the increase in the yield was significant upto Zn application @ $5 \mathrm{~kg} \mathrm{ha}^{-1}$ in pooled analysis which was found statistically at par with Zn@6 kg ha-1.

The data further revealed that the per cent increase in seed yield, haulm yield and biological yield were in order of 72.53 , 50.08 and 57.68 in pooled analysis due to application of $5 \mathrm{~kg} \mathrm{Zn}$ $\mathrm{ha}^{-1}$ as compared to control. Habib et al. (2018) reported that zinc fertilization significantly increased the yield attributes and yield of blackgram upto $2.5 \mathrm{~kg} \mathrm{Zn} \mathrm{ha-1.} \mathrm{Sudharsan} \mathrm{and} \mathrm{Ramaswami}$ (1993) reported that even residual effects of zinc sulphate also contribute to high yield in blackgram crop due to increased supply of available zinc in zinc deficient soil and role of zinc in biosynthesis of indole acetic acid and in initiation of primordial of reproductive parts and partitioning of photosynthates towards them (Wear and Hagler, 1963; Baker et al., 1982). Zinc application increased the seed yield probably owing to its influence on auxin synthesis, nodulation, nitrogen fixation, carbohydrate and nitrogen metabolism which promoted plant growth and development, there by favourably influencing grain and biological yield (Marschner, 1995; Mahilane and Singh, 2018). The application of increasing levels of zinc from $3 \mathrm{~kg}$ to $6 \mathrm{~kg}$ $\mathrm{Zn}$ ha ${ }^{-1}$ significantly increased the nutrient content and uptake by seed and haulm of blackgram (Table 2). The maximum significant

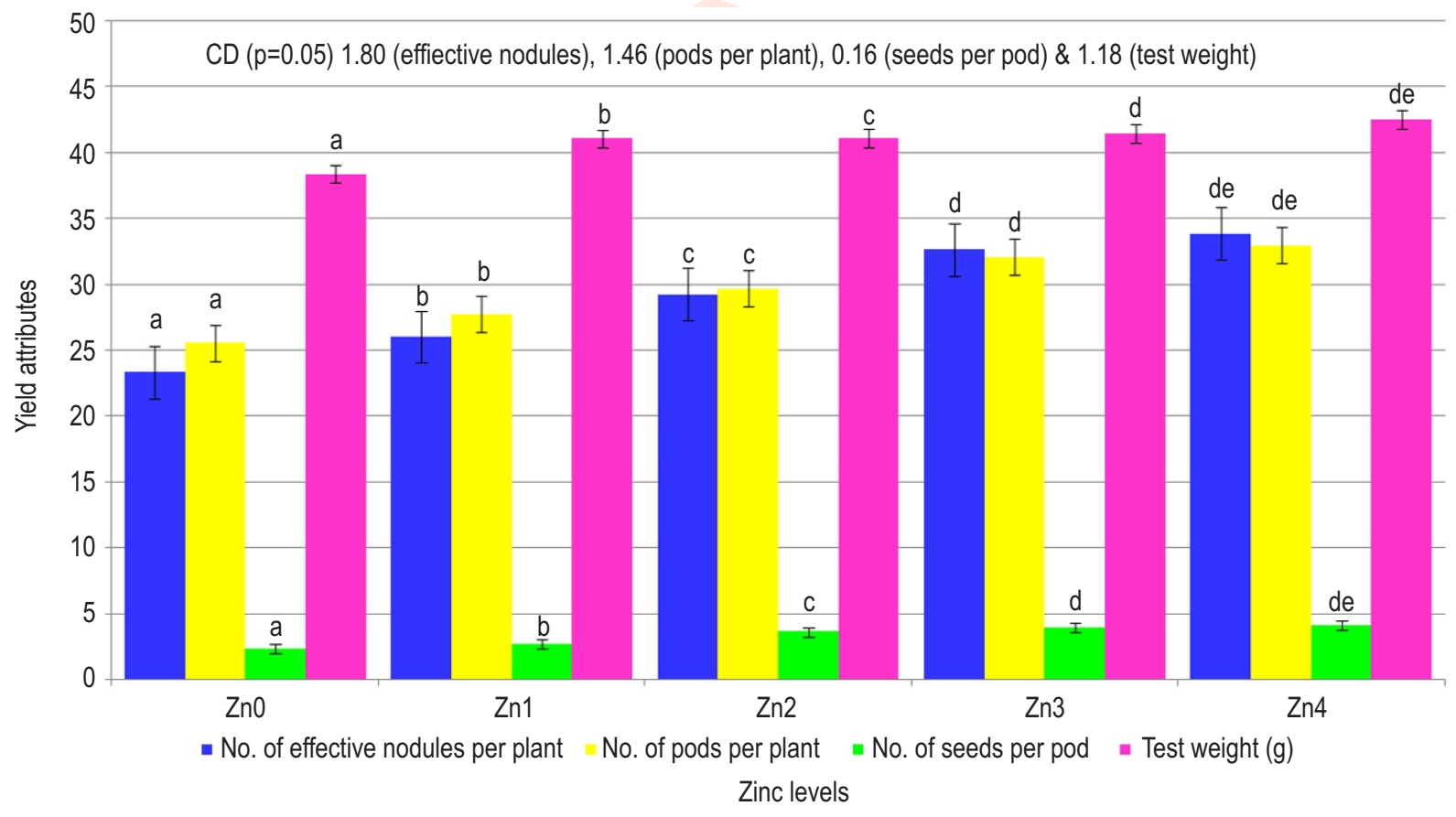

Fig. 1: Effect of soil application of zinc on number of effective nodules per plant, number of pods per plant, number of seeds per pod and test weight of blackgram in Typic Haplustepts soil of Rajasthan (pooled basis); ${ }^{*}$ Error bars indicates the standard error of mean; ${ }^{* *}$ Columns marked with same letters are statistically similar at $p=0.05$. 

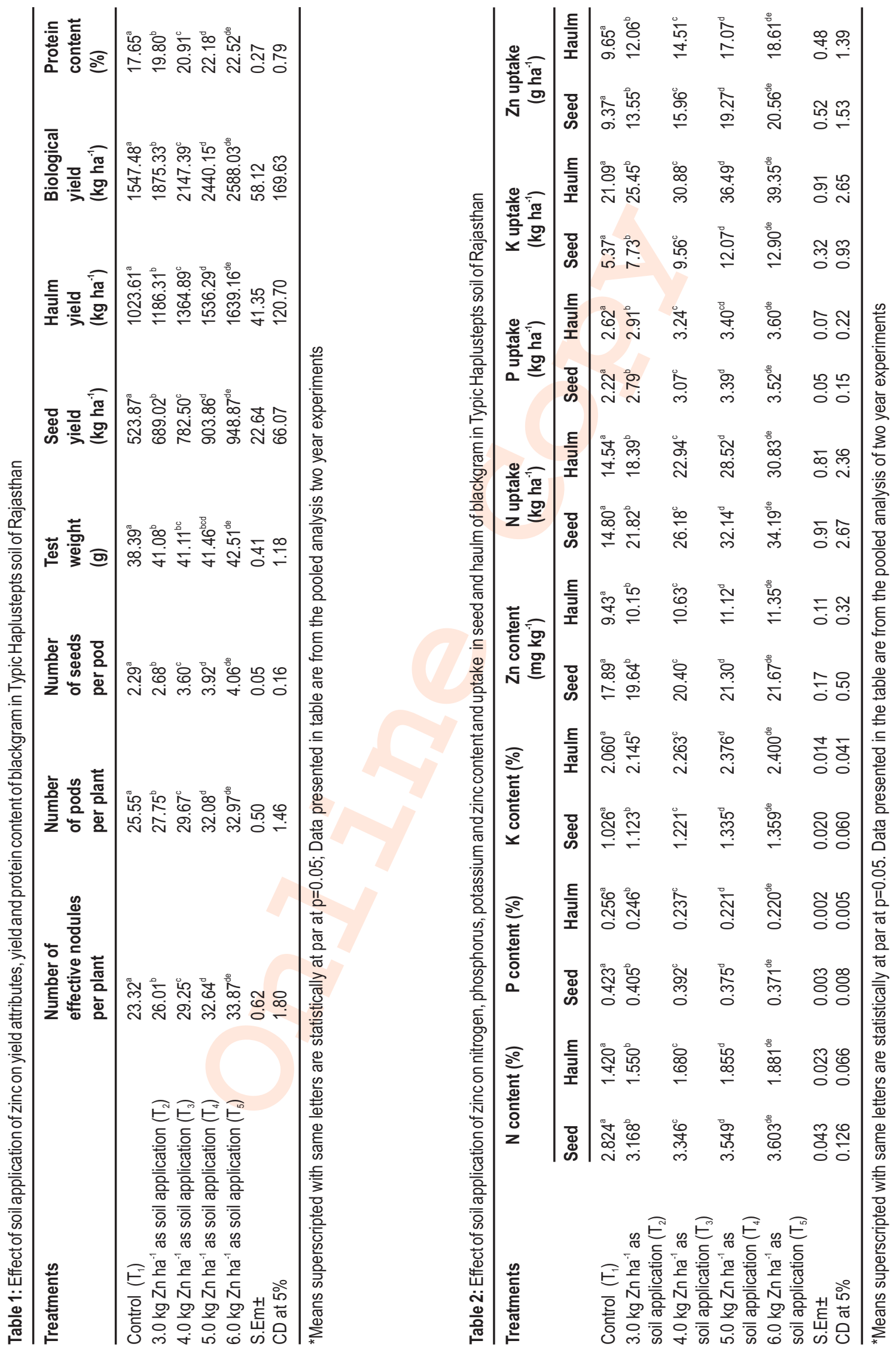
nutrient content and uptake ( $\mathrm{N} 3.549 \%$ and $32.14 \mathrm{~kg} \mathrm{ha}^{-1}$ in seed and $\mathrm{N} 1.855 \%$ and $28.52 \mathrm{~kg} \mathrm{ha}^{-1}$ in haulm, P $3.39 \mathrm{~kg} \mathrm{ha}^{-1}$ in seed and $3.40 \mathrm{~kg} \mathrm{ha}^{-1}$ in haulm, $\mathrm{K} 1.335 \%$ and $12.07 \mathrm{~kg} \mathrm{ha}^{-1}$ in seed and $\mathrm{K} 2.376 \%$ and $36.49 \mathrm{~kg} \mathrm{ha}^{-1}$ in haulm and $\mathrm{Zn} 21.30 \mathrm{mg} \mathrm{kg}^{-1}$ and $19.27 \mathrm{~g} \mathrm{ha}^{-1}$ in seed and $\mathrm{Zn} 11.12 \mathrm{mg} \mathrm{kg}^{-1}$ and $17.07 \mathrm{~g} \mathrm{ha}^{-1}$ in haulm) of blackgram was recorded under Zn @ $5 \mathrm{~kg} \mathrm{ha}^{-1}$ in pooled analysis. However, the increase in the nutrient content and uptake was significant upto $5 \mathrm{~kg} \mathrm{ha}^{-1}$ of $\mathrm{Zn}$ application in pooled analysis which was found statistically at par with Zn applied @ 6 $\mathrm{kg} \mathrm{ha}^{-1}$. In contrast to this, application of zinc significantly decreased the phosphorus content in seed and haulm of blackgram as compared to control in pooled analysis (Table 2).

The increase in the nutrient content and uptake in blackgram might be due to the synergistic interaction of zinc with nitrogen and potassium whereas nitrogen content and uptake in seed and haulm of blackgram could be due to higher availability of zinc by plant resulting in better metabolism for the production of carbohydrate, lipids and proteins. Keram et al. (2012) reported synergistic effect between nitrogen and zinc. The increase in potassium content and uptake due to interaction of potassium and zinc could be due to improved of enzymatic activities and metabolic processes of plant with both the nutrients which might have ultimately facilitated the removal of potassium from soil and consequently increased the yield of blackgram (Todawat et al., 2017). Shivay et al. (2015) demonstrated that phosphorus content in seed and haulm of blackgram decreased with increasing level of zinc due to the antagonistic effect of zinc on phosphorus absorption. The results are in agreement with the findings observed by Dewal and Pareek (2004), Todawat et al. (2017) and Ranpariya and Polara (2018).

The maximum protein content in seeds of blackgram (22.18\%) was found with the application of Zn@ $5 \mathrm{~kg} \mathrm{ha}^{-1}$ (Table 1). However, the effect 5 and $6 \mathrm{~kg} \mathrm{Zn} \mathrm{ha}^{-1}$ application on protein content in seeds of blackgram was found statistically at par in pooled analysis. The data further revealed that per cent increase in protein content in seed due to application of $5 \mathrm{~kg} \mathrm{Zn} \mathrm{ha}^{-1}$ was to the tune of 25.66 in pooled analysis as compared to control. The significant increase in protein content in seed may be due to high nitrogen content in seed on the application of higher dose of zinc. Application of zinc increased the activity of nitrate reductase enzymes which activated the nitrogen uptake by the plants, thereby increasing the protein content in seed. Higher nitrogen content in seed is directly responsible for higher protein as nitrogen is a primary component of amino acids required for protein synthesis. This might be the consequence of zinc fertilizer as it promotes synthesis of IAA, nodulation and nitrogen fixation process in plant and soil, respectively (Ahlawat et al., 2007). Shukla (2013) concluded that the increase in dose of zinc fertilizer increased the percent protein content in seed of blackgram. The positive effect of zinc application on increasing seed protein content was reported by Seadh et al. (2009) and El-Habbasha et al. (2015). Broadley et al. (2007) reported zinc functions related protein synthesis and its effect on protein functions. Similarly, Cakmak et al. (2010) reported that there is a close positive correlation between zinc concentration and protein content. The results from the pooled data of two year study indicated that the application of increasing levels of zinc significantly increased the net return and $\mathrm{B}: \mathrm{C}$ ratio of blackgram. The maximum net return (Rs.36419 ha ${ }^{-1}$ ) and B:C ratio (2.22) was recorded under Zn @5 $\mathrm{kg} \mathrm{ha}^{-1}$ in pooled analysis which was found statistically at par with Zn@6 kg ha ${ }^{-1}$. High net return and B:C ratio observed due to application of zinc were also reported previously by Jat et al. (2018) and Todawat etal. (2018).

The present study provides increasing evidence to show that the soil application of Zn @ $5 \mathrm{~kg} \mathrm{ha}^{-1}$ along with recommended dose of NPK is highly effective and a very practical way to maximize blackgram yield and economic gains. In conclusion, the soil zinc application favors the supply of zinc required for maximum yield production and will be highly useful in the soils which are medium in organic carbon and suffer from multi-nutrient deficiencies (N, P, S, Zn, Fe and B).

\section{Acknowledgments}

We acknowledge the support of Directorate of Research, Maharana Pratap University of Agriculture \& Technology, Udaipur, Rajasthan for providing facilities, technical help and necessary guidance for the study.

\section{Add-on Information}

Authors' contribution: G. Jat and S.K. Sharma: Conceived and designed the experiment; R. H. Meena, R. Choudhary, R.S. Choudhary and S.K. Yadav: Performed field experiment and laboratory works; G. Jat, D. Jain and S.K. Sharma: Manuscript writing and data analysis.

Research content: The research content is original and has not been published elsewhere.

\section{Ethical approval: NotApplicable.}

Conflict of interest: The authors declare that there is no conflict of interest.

Data from other sources: NotApplicable.

Consent to publish: All authors agree to publish the paper in Journal of Environmental Biology.

\section{References}

A.O.A.C.: Association of Official Agricultural Chemists. Official Methods of Analysis. 8th Education Association Official Agricultural Chemists. Washington. D.C. (1960).

Ahlawat, I.P.S., B. Gangaiah and M.A. Zadid: Nutrient management in chickpea. In: Chickpea Breeding and Management (Eds.: S.S. Yadav, R. Redden, W. Chen and B. Sharma). CAB International, Wallingford, Oxon, United Kingdom, pp. 213-232 (2007).

Alloway, B. J.: Zinc in Soils and Crop Nutrition. $2^{\text {nd }}$ Edn., IZA Brussels, 
Belgium and IFA, Paris, France (2008).

Arunachalam, P., P. Kannan, G. Prabukumar and M. Govindaraj: Zinc deficiency in Indian soils with special focus to enrich zinc in peanut. Afri. J. Agril. Res., 8, 6681-6688 (2013).

Aziz, M.Z., M. Yaseen, T. Abbas, M. Naveed, A. Mustafa, Y. Hamid, Q. Saeed and X.U. Ming-gang: Foliar application of micronutrients enhance crop stand, yield and the biofortification essential for human health of different wheat cultivars. J. Integ. Agri., 18, 1369-1378 (2018).

Baker, N.R., P. Fernyhough and I.T. Meek: Light dependent inhibition of photosynthetic electron transport by zinc. Physiol. Plantarum, 56, 217-222 (1982).

Bhatt, R., A. Hossain and P. Sharma: Zinc biofortification as an innovative technology to alleviate the zinc deficiency in human health: A review. OpenAgri., 5, 176-187 (2020).

Broadley, M., P. White, J. Hammond, I. Zelko and A. Lux: Zinc in plants. New Phytol., 173, 677-702 (2007).

Cakmak, I. and U.B. Kutman: Agronomic biofortification of cereals with zinc: Areview. Eur. J. Soil Sci., 69, 172-180 (2018).

Cakmak, I.: Zinc deficiency in wheat in Turkey. In: Micronutrients deficiencies in global crop production. (Ed.: B.J. Alloway). New York: Springer, pp.181-200 (2008).

Cakmak, I., M. Kalayci, Y. Kaya, A.A. Torun, N. Aydin and Y. Wang: Biofortification and localization of zinc in wheat grain. J. Agril. Food Chem., 58, 9092-9102 (2010).

Dewal, G.S. and R.G. Pareek: Effect of phosphorus, sulphur and zinc on growth, yield and nutrient uptake of wheat. Ind. J. Agron., 49, 160$162(2004)$.

Dubey, S.K., S.K. Tripathi and B. Singh: Effect of sulphur and zinc levels on growth, yield and quality of mustard [Brassica juncea (L.) Czern \& Coss.]. Res. Rev.:A J. Crop Sci. Tech., 2, 1-10 (2013).

El-Habbasha, E.S., E.A. Badr and E.A. Latef: Effect of zinc foliar application on growth characteristics and grain yield of some wheat varieties under $\mathrm{Zn}$ deficient sandy soil condition. Int. J. Chem. Tech. Res., 8, 452-458 (2015).

Habib, A.S.Md.A., T.S. Roy, Md. R. Amin, Md. Z. Haque, Md. Rokonuzzaman and P. Sarker: Response of zinc on growth, yield and quality of blackgram (Vigna mungo L.). Int. J. Agron. Agri. Res. 13, 73-79 (2018).

Jackson, M.L.: Soil Chemical Analysis. Prentice Hall of India Pvt. Ltd., New Delhi, pp. 263-393 (1973).

Jat, G., K.K. Sharma and N.K. Jat: Effect of FYM and mineral nutrients on physio-chemical properties of soil under mustard in western arid zone of India. Ann. Plant Soil Res., 14, 167-170 (2013).

Jat, G., S.K. Sharma and R.H. Meena:Amelioration of zinc deficiencies in mustard through foliar spray of zinc and vermiwash. Ind. J. Fert., 14, 40-42 (2018).

Keram, K.S., B.L. Sharma and S.D. Sawarkar: Impact of zinc application on yield, quality, nutrient uptake and soil fertility in medium deep black soil (Vertisol). Int. J. Sci., Environ. Tech., 1, 563-571 (2012).

Khoshgoftarmanesh, A.H., R. Schulin, R.L. Chaney, B. Daneshbakhsh and M. Afyuni: Micronutrient-efficient genotypes for crop yield and nutritional quality in sustainable agriculture: A review. Agron. Sust. Develop., 30, 83-107 (2010).

Lindsay, W.L. and W.A. Norvell: Development of DTPA soil test for zinc, iron, manganese and copper. Soil Sci. Soc. Am. J., 42, 421-442 (1978).

Mahilane, C. and V. Singh: Effect of zinc and molybdenum on growth, yield attributes, yield and protein in grain on summer blackgram (Vigna mungo). Int. J. Curr. Microbio. App. Sci., 7, 1156-1162 (2018).
Manojlovic, M.S., Z. Loncaric, R.R. Cabilovski, B. Popovic, K. Karalic, V. Ivezic and B.R. Singh: Bio-fortification of wheat cultivars with selenium. Acta. Agric. Scand. B Soil Plant Sci.,1, 10 (2019).

Marschner, H.: Mineral Nutrition of Higher Plants. Academic Press, New York, pp. 347-364 (1995).

Meena, K.C. and L.K. Meena: Performance of Pratap Urd 1 variety of blackgram in agro-climatic zone-V of Rajasthan. J. Krishi Vigyan, 8, 210-214 (2020).

Mony, S. A., M.S. Haque, M.A. Karim and S.K. Roy: Callus induction and plantlet regeneration in blackgram (Vigna mungo L. Hepper). Progress. Agric., 19, 27-35 (2008).

Panse, V. G. and P.V. Sukhatme: Statistical Methods for Agricultural Workers. ICAR, New Delhi (1985).

Ranpariya, V.S. and K.B. Polara: Effect of potassium, zinc and FYM on content and uptake on summer greengram (Vigna radiata) at different growth stages under south Saurashtra region of Gujarat. Ind. J. Pure App. Biosci., 6, 997-1002 (2018).

Roy, P. D., R.P. Narwal, R.S. Malik, B.N. Saha and S. Kumar: Impact of zinc application methods on green gram (Vigna radiata L.) productivity and grain zinc fortification. J. Environ. Bio., 35, 851854 (2014).

Seadh, S.E., M.I. El-Abady, A.M. El-Ghamry and S. Farouk: Influence of micronutrient application and nitrogen fertilization on wheat yield, quality of grain. Int. J. Bio. Sci., 9, 851-858 (2009).

Sharma, V. and T. Abraham: Response of blackgram (Phaseolus mungo) to nitrogen, zinc and farmyard manure. Leg. Res., 33, 295-298 (2010).

Shivay, Y.S., R. Prasad, R.K. Singh and M. Pal: Relative efficiency of zinc-coated urea and soil and foliar application of zinc sulphate on yield, nitrogen, phosphorus, potassium, zinc and iron biofortification in grains and uptake by Basmati rice (Oryza sativa L.). J. Agril. Sci., 7, 161-173 (2015).

Shukla, K.: Evaluation of zinc application methods to enhance yield and quality of blackgram. Glob. J. Cur. Res., 1, 50-56 (2013).

Singh, A.: Estimating long-term regional groundwater recharge for the evaluation of potential solution alternatives to water logging and salinization. J. Hydro., 400, 245-255 (2011).

Singh, M. and K.S. Singh: Zinc and copper status of soil of Rajasthan. Ann. Arid Zone, 20, 77 (1981).

Snell, F.D. and C.P. Snell: Colorimetric Methods of Analysis. $3^{\text {rd }}$ Edn., Vol. $2^{\text {nd }} . D$. Van Nostrand Inc. New York (1949).

Sudarasan, S. and P.P. Ramaswami: Micronutrient nutrition in groundnut - blackgram cropping system. Fert. News, 38, 51-57 (1993).

Takkar, P.N. and N.S. Randhawa: Micronutrients in Indian Agriculture-A Review. Ferti. News, 23, 8-26 (1978).

Todawat, A., G. Jat, H. Lakhran and S. Aechra: Response of greengram (Vigna radiata L.) to levels of vermicompost and zinc under loamy sand soil. Int. J. Agril. Sci. Res., 8, 33-38 (2018).

Todawat, A., S.R. Sharma, H. Lakharan and Hemraj: Effect of vermicompost and zinc on growth, yield attribute and yield of greengram (Vigna radiate L.) under semi-arid region of Rajasthan. Intern. J. Curr. Microbio. App. Sci., 6, 175-180 (2017).

Upadhyay, R.G. and A. Singh: Effect of nitrogen and zinc on nodulation, growth and yield of cowpea [Vigna unguiculata L. Walp]. Leg. Res., 39, 149-151 (2016).

Vedram, S.K. Mishra and R.H. Upadhyay: Effect of sulphur, zinc and biofertiliser on quality characteristics on mungbean. Ind. J. Pul. Res., 15, 139-141 (2002).

Wear, J.I. and T.B. Hagler: Zinc status and needs of the southern region. PlantFood. Rev., 9, 2-5 (1963). 